Federal Reserve Bank of Minneapolis

Research Department Staff Report 421

Revised March 2009

\title{
The Current Financial Crisis: \\ What Should We Learn from the \\ Great Depressions of the Twentieth Century?*
}

\author{
Gonzalo Fernández de Córdoba \\ Universidad de Salamanca \\ Timothy J. Kehoe \\ University of Minnesota, \\ Federal Reserve Bank of Minneapolis, \\ and National Bureau of Economic Research
}

\begin{abstract}
Studying the experience of countries that have experienced great depressions during the twentieth century teaches us that massive public interventions in the economy to maintain employment and investment during a financial crisis can, if they distort incentives enough, lead to a great depression.
\end{abstract}

\footnotetext{
*This paper is a translation of "La Crisis Financiera Actual: ¿Qué Debemos Aprender de las Grandes Depresiones del Siglo XX?" by the same authors. We thank Juan Carlos Conesa, Ed Prescott, and Art Rolnick for helpful comments and suggestions. We are grateful to the Proyecto de Excelencia P07-SEJ-02479 of the Junta de Andalucía, and Kehoe is grateful to the National Science Foundation for financial support under grant SES0536970. The views expressed herein are those of the authors and not necessarily those of the Federal Reserve Bank of Minneapolis or the Federal Reserve System. e-mail addresses: gfdc@usal.es and tkehoe@umn.edu. URLs: web.usal.es/ gfdc and www.econ.umn.edu/ tkehoe.
} 
The current financial crisis has prompted these questions: Could the world economy enter a great depression like that of the 1930s? If so, what can governments do to avoid it?

Looking at historical experience can help us answer these questions. Since 2000, Timothy Kehoe and Edward Prescott have been running a project at the Federal Reserve Bank of Minneapolis to study the great depressions that occurred during the twentieth century. Kehoe and Prescott define a great depression to be a very large and sustained drop in output per working-age person below trend growth.

\section{Real GDP per working-age person in the United States}

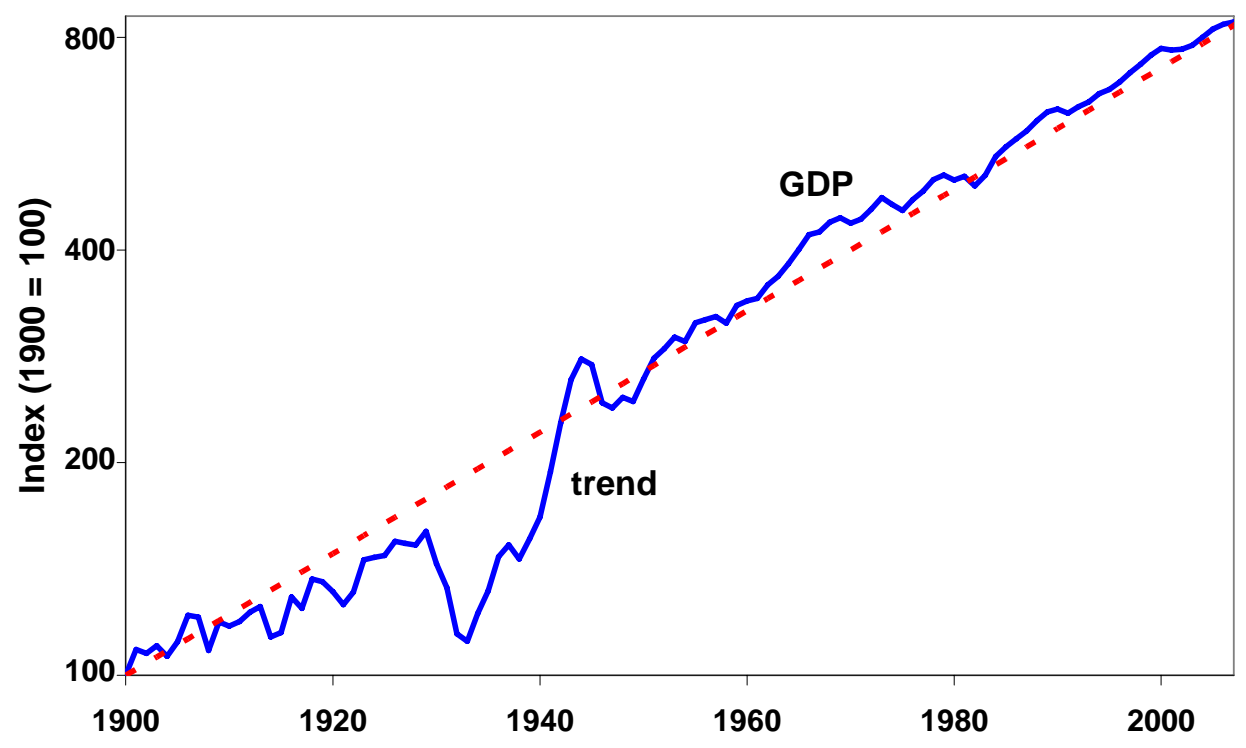

To get an idea of how different a great depression is from an ordinary business cycle downturn, we can look at a graph of real GDP per person aged 15-64 in the United States over the period 1900-2007. On a logarithmic scale, we see that the business cycle fluctuations around a trend growth line of 2 percent per year are very small. In contrast, the great depression of 1929-39 and the subsequent World War II buildup are huge deviations from trend growth.

In the book Great Depressions of the Twentieth Century, published in 2007 by the Federal Reserve Bank of Minneapolis, Kehoe and Prescott, together with a team of 24 economists from all over the world, have studied the great depressions that occurred in North America and Western Europe in the 1930s, those that occurred in Latin America in the 1980s, and isolated 
experiences in other places and times. What lessons can be learned from comparing and contrasting these historical experiences? The authors of each of the studies in the book start by decomposing the decline in output during the depression into declines in inputs of labor and capital and a decline in the efficiency with which these factors are employed, measured as productivity. They find that a large drop in productivity always plays a large role in accounting for the depression. In some depressions, such as the U.S. depression of the 1930s, large drops in labor inputs also play important roles. In others, such as the Mexican depression of the 1980s, the drop in productivity accounts for almost the entire drop in output.

Looking at the historical evidence, Kehoe and Prescott conclude that bad government policies are responsible for causing great depressions. In particular, they hypothesize that, while different sorts of shocks can lead to ordinary business cycle downturns, overreaction by the government can prolong and deepen the downturn, turning it into a depression.

An instructive exercise is to compare the experiences of Chile and Mexico in the 1980s studied in the chapter in the depressions book by Raphael Bergoeing, Patrick Kehoe, Timothy Kehoe, and Raimundo Soto. In 1981-82, both countries were hit by the shocks of rising world interest rates and falling international prices of the commodities that they exported - copper for Chile and petroleum for Mexico. These shocks exposed weakness in the banking systems in both countries and produced financial crises.

In 1982 in Chile, banks that held half of the deposits were suffering severe liquidity crises. The government took control of these banks. Within three years, the Chilean government had liquidated the insolvent banks and reprivatized the solvent banks. The government set up a new regulatory scheme to avoid mismanagement. These new regulations allowed the market to determine interest rates and the allocation of credit to firms. The short-term costs of the crisis and the reform in Chile were severe, and real GDP fell sharply in 1982 and 1983. By 1984, however, the Chilean economy started to grow, and Chile has been the fastest-growing country in Latin America since then.

In 1982 in Mexico, the government nationalized the entire banking system, and banks were only reprivatized in the early 1990s. Throughout the 1980s, in an effort to maintain employment and investment, the government-controlled banks provided credit at below-market interest rates to 
some large firms and no credit to others. Even the privatization of banks in the early 1990s and the reforms following the 1995 crisis have not been effective in producing a banking system that provides substantial credit at market interest rates to firms in Mexico. The result has been an economic disaster for Mexico: Between 1982 and 1995, Mexico experienced no economic growth and has grown only modestly since then.

Real GDP per working age person in Chile and Mexico

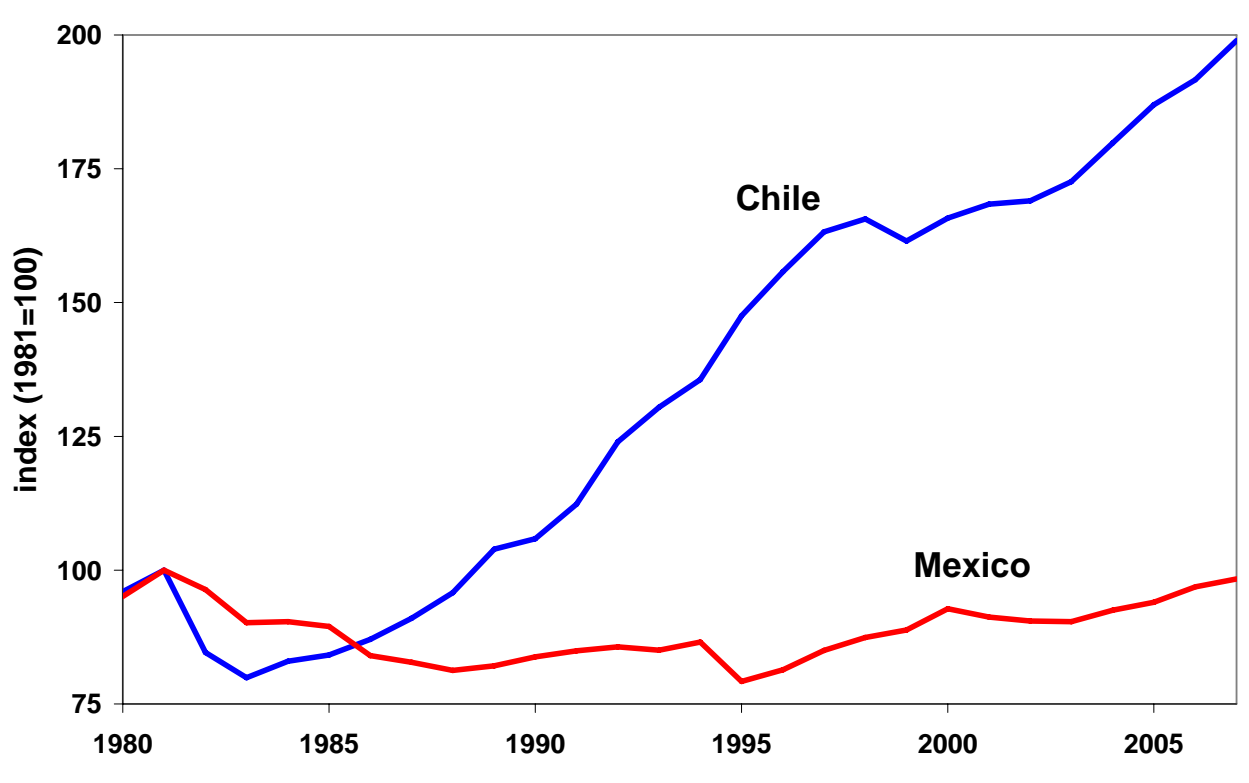

The differences in economic performance in Chile and Mexico since the early 1980s have not been in employment and investment, but in productivity. In Chile, unproductive firms have died and new firms have been born and grown. Workers and capital have been channeled from unproductive to productive firms. In Mexico, a poorly functioning financial system has impeded this process.

Some features of the situations in Chile and Mexico in the 1980s should make us cautious in generalizing the lessons learned in studying their crises to the current crisis in North America and Western Europe: Chile and Mexico were poorer and were in a financial crisis that was largely restricted to Latin America. Furthermore, Chile undertook its massive and costly reforms when its government was a military dictatorship, which eliminated the need to obtain difficult political consensus. 
Nevertheless, the central lessons from studying Chile and Mexico can be generalized. Consider the crises in Finland and Japan, also studied in the depressions book — Finland by Juan Carlos Conesa, Timothy Kehoe, and Kim Ruhl, and Japan by Fumio Hayashi and Edward Prescott. Japan suffered a financial crisis in the early 1990s and followed similar sorts of policies as Mexico, keeping otherwise insolvent banks running, providing credit to some firms and not others, and using massive fiscal stimulus programs to maintain employment and investment. Japan has stagnated since then. Finland also suffered a financial crisis in the early 1990s and followed similar sorts of policies as Chile, paying the costs of reform and letting the market dictate the allocation of credit to the private sector. The Finnish economy has grown spectacularly since then.

\section{Real GDP per working age person in Finland and Japan}

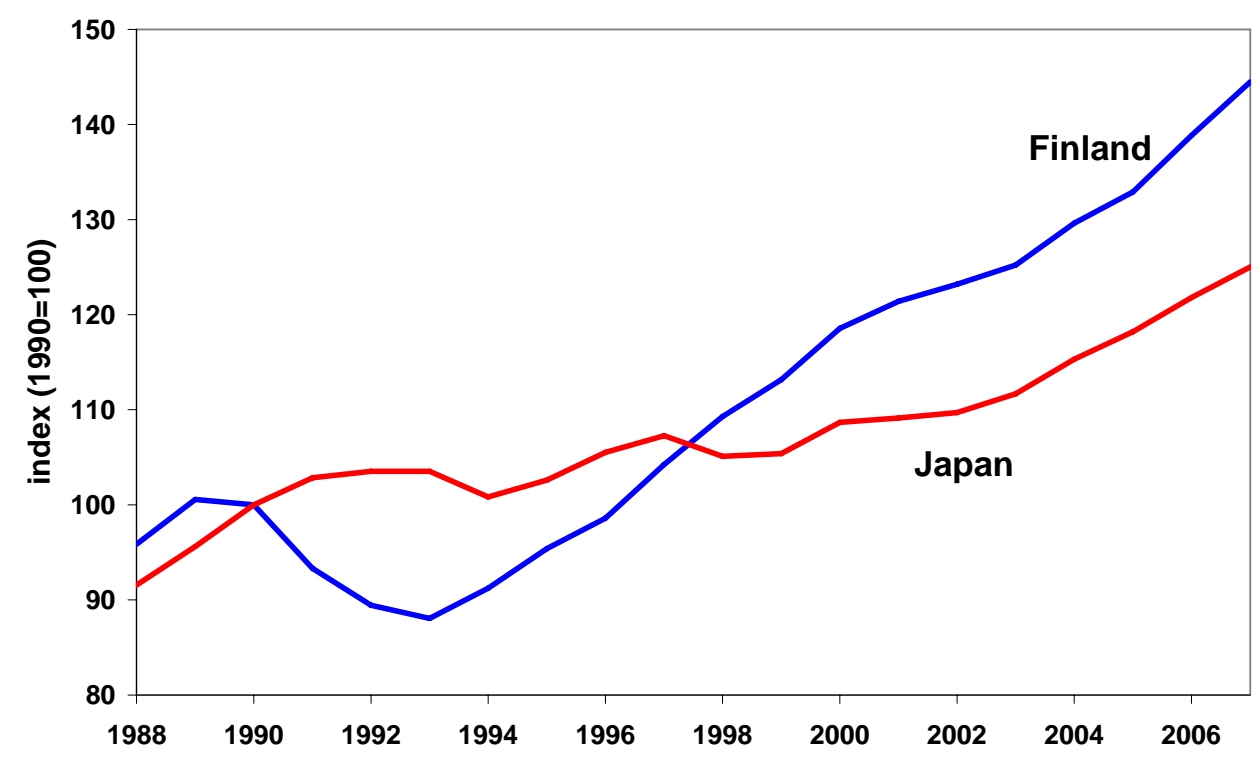

Now it is the countries of North America and Western Europe that find themselves in a financial crisis. To emerge from the crisis as did Chile and Finland, and not become trapped in stagnation as did Mexico and Japan, we need to avoid implementing policies that stifle productivity by providing bad incentives to the private sector. With banks and other financial institutions in crisis, the government needs to focus on providing liquidity so that banks can provide credit at market interest rates, and using the market mechanism, to productive firms. Unproductive firms need to die. This is as true for the automobile industry as it is for the banking system. Bailouts and other financial efforts to keep unproductive firms in operation depress productivity. These 
firms absorb labor and capital that are better used by productive firms. The market makes better decisions than does the government on which firms should survive and which should die.

Different sorts of shocks can start financial crises. Some shocks are external to the economy. In the cases of Chile and Mexico, it was the increase in world interest rates and the decrease in international commodity prices, and in the case of Finland, it was collapse in trade with the former Soviet Union. Some shocks are internal. In the case of Japan, it was the fall in the prices of commercial real estate, and, currently in North America and Western Europe, it is the fall in the prices of residential real estate. The analysis of great depressions shows that the type of shock that starts the depression is less important than reaction to the shock by the economy and, in particular, the government.

Over the past decade, lending by China and other countries in East Asia, fueled by massive trade surpluses, have kept world interest rates low. Consumers in North America and Western Europe have benefited from these low interest rates and have consumed and invested more. Much of the increased investment has been in residential real estate. In the United States, much of this investment has been concentrated in certain cities and regions. In Europe, much of it has been concentrated in Spain. In a more integrated Europe, Spain has the same natural role as Florida and Arizona have in the United States. There is nothing wrong with investment in real estate or with the investment being concentrated as long as investors understand the risks.

The specific problem with the real estate boom of the early 2000s was that it generated an aggregate risk when most investors were betting that housing prices could go in no other direction but up. The systemic risk created by the possibility of housing prices falling was a problem precisely because banks, regulators, and bond ratings agencies either did not understand that this risk existed or did not understand its implications. When housing prices fell, many mortgage-backed bonds that were rated AAA by ratings agencies turned out to be riskier than Argentinean government bonds in the late 1990s. If the risk of a fall in housing prices had been understood and priced correctly, higher interest rates on lending for construction projects and mortgages would have corrected the problem. The lack of understanding of systemic risk on the part of banks, regulators, and bond ratings agencies calls for reform and, perhaps, new regulations. 
The fall in housing prices has exposed an even more fundamental problem in the financial system. Some investors and policy makers have come to regard some financial institutions, and even some manufacturing firms, as being too big to fail. In the banking system, a tension exists between the government insuring depositors in banks and in regulating the banks. The fundamental principle involved in efficiently allocating risk is that any insurance should be accompanied by regulation. Any institution that is too big to fail needs to be regulated.

Governments are now spending huge sums of public money to bail out financial institutions that had not been previously regulated. Even aside from the costs of generating the need for more taxes, these bailouts will create difficulties for the future. Risky investments will pay returns in spite of bad outcomes. Labor and capital will stay employed in unproductive uses. Incentives for future investment will be distorted by moral hazard problems. We got into the financial crisis that we are in now because of poor assessments of risk. Indiscriminate bailouts in the financial sector will reward many of those who made bad decisions and make it even more difficult to assess risks in the future. Understanding the moral hazard problems created by bailouts, many citizens and politicians will call for massive regulation of all financial institutions. Directly and indirectly, massive and indiscriminate bailouts of the financial system will create inefficiency and low productivity.

What do we need to do now? The central banks in the countries that are in crisis should lend to banks to maintain liquidity. Any bailouts of nonbank financial institutions should be accompanied, at least temporarily, by strict regulations. The bailout should not be used to maintain high returns either to the equity holders or to the bond holders in these institutions. Investors who made risky investments should not be rewarded when these investments have gone bad. Any public spending on investment in infrastructure should be justified on its own merits, especially in terms of its potential for increasing productivity. Otherwise, we should let the market work in letting unproductive firms go bankrupt and reallocating what remains of their resources to more productive firms. Reforming bankruptcy laws in some countries could make this process more efficient.

The people and the governments of some countries may decide that there should be some sort of social insurance for workers who lose their jobs, for households who lose their homes, and even 
for firms in some sectors or regions. If so, this insurance should be provided directly and not indirectly through massive and indiscriminate bailouts of firms.

There are costs to be paid for the past mistakes that we have made, but, if we use this opportunity to make reforms and reallocate resources to more productive uses, the economies of North America and Western Europe can emerge from the current crisis as Chile and Finland did from theirs, quickly and stronger than ever. We should bear in mind, however, that as bad as the current situation is, it could get worse. If the financial crisis has the effect of stopping the flow of savings from China and other countries in East Asia to the rest of the world, interest rates will rise, making the adjustment more difficult.

Studying the experience of countries that have experienced great depressions during the twentieth century teaches us that massive public interventions in the economy to maintain employment and investment during a financial crisis can, if they distort incentives enough, lead to a great depression. Those who try to justify the sorts of Keynesian policies implemented by the Mexican government in the 1980s and the Japanese government in the 1990s often quote Keynes's dictum from A Tract on Monetary Reform: "The long run is a misleading guide to current affairs. In the long run we are all dead.” Studying past great depressions turns this dictum on its head: "If we do not consider the consequences of policy for productivity, in the long run we could all be in a great depression.” 


\section{References}

Bergoeing, Raphael, Patrick J. Kehoe, Timothy J. Kehoe, and Raimundo Soto (2007), “A Decade Lost and Found: Mexico and Chile in the 1980s," in Timothy J. Kehoe and Edward C. Prescott, editors, Great Depressions of the Twentieth Century, Federal Reserve Bank of Minneapolis, 217-256.

Conesa, Juan Carlos, Timothy J. Kehoe, and Kim J. Ruhl, (2007), “Modeling Great Depressions: The Depression in Finland in the 1990s," in Timothy J. Kehoe and Edward C. Prescott, editors, Great Depressions of the Twentieth Century, Federal Reserve Bank of Minneapolis, 427-475.

Hayashi, Fumio and Edward C. Prescott (2007), “The 1990s in Japan: A Lost Decade,” in Timothy J. Kehoe and Edward C. Prescott, editors, Great Depressions of the Twentieth Century, Federal Reserve Bank of Minneapolis, 257-285.

Kehoe, Timothy J. and Edward C. Prescott, editors (2007), Great Depressions of the Twentieth Century, Federal Reserve Bank of Minneapolis.

Keynes, John Maynard (1924), A Tract on Monetary Reform, Macmillan. 